\title{
PENDAMPINGAN USAHA BETERNAK SECARA MANDIRI DAN PEMBUATAN LUMBUNG TRIGONA TETEBATU (LITEBA) DI DESA TETEBATU KECAMATAN SIKUR LOMBOK TIMUR
}

\author{
Supporting An Independent Husbandry Business And Making Trigona House \\ Tetebatu (Liteba) In Tetebatu Village, East Lombok
}

\author{
Dwi Kusuma Purnamasari", Pardi, Ketut Gede Wiryawan, Syamsuhaidi, Erwan, Yulian \\ Asronul Lutfi, dan Rohmah
}

Program Studi Peternakan Universitas Mataram

Jl. Majapahit No. 62 Mataram 83125

*Alamat korespondensi : emmadkp03@ygmail.com

(Tanggal Submission: 9 November 2020, Tanggal Accepted: 28 Desember 2020)

\begin{abstract}
Kegiatan pengabdian bertujuan untuk menyebarkan informasi, pengetahuan dan keterampilan dalam usaha beternak secara mandiri berbasis bahan pakan lokal dan alternatif dan penyampaian program pembuatan Lumbung Trigona Tete Batu (Liteba). Kegiatan ini didasarkan pada potensi Desa Tetebatu sebagai daerah pertanian yang subur sehingga ketersediaan limbah pertanian melimpah dan selama ini belum dimanfaatkan secara maksimal sebagai pakan ternak khususnya ternak unggas yang permasalahan utamanya pada bahan pakan yang mahal, selain itu vegetasi tanaman yang bervariasi dan melimpah menjadi sumber nektar dan pollen bagi lebah untuk menghasilkan madu. Kegiatan pengabdian dilakukan melalui pemberian materi tentang managemen beternak unggas, bahan-bahan pakan lokal yang bisa dijadikan sebagai bahan pakan alternatif, dan penyampaian pembuatan 'Liteba' oleh mahasiswa peternakan. Khalayak sasaran dari kegiatan pengabdian ini adalah masyarakat yang bekerja di bidang pertanian dan peternakan, pengurus desa, dan tokoh-tokoh masyarakat desa, serta kelompok pemuda desa. Kegiatan pengabdian menghasilkan peningkatan motivasi dan semangat dalam mengembangkan usaha peternakan menjadi mata pencaharian yang utama dan pengurus desa serta tokoh masyarakat desa ikut mendukung dengan menjadikan salah satu program unggulan desa selain bidang pariwisata. Berdasarkan hasil evaluasi telah berdiri lumbung trigona dan telah berproduksi menghasilkan madu untuk dijual ke konsumen. Komitmen dari pemerintah daerah yang terkait menjadi penguat keberhasilan kegiatan ini.
\end{abstract}

Kata kunci: pengembangan, usaha, peternakan, madu 


\section{PENDAHULUAN}

Desa Tetebatu merupakan salah satu desa yang berada di wilayah Kecamatan Sikur Kabupaten Lombok Timur Provinsi Nusa Tenggara Barat dan berbatasan langsung dengan kawasan dengan kawasan Taman Nasional Gunung Rinjani (TNGR). Dilihat dari letak geografis wilayahnya, Desa Tetebatu berada di ketinggian 700/9000 mdpl dengan topografi wilayah berbukit yang digunakan untuk areal persawahan, perkebunan dan pemukiman warga. Curah hujan rata-rata 4000 $\mathrm{mm} /$ tahun dengan jumlah curah hujan 6 bulan dan suhu rata-rata hariannya 250 C. Secara administratif, Desa Tetebatu terdiri dari 5 Dusun, ddan 40 RT, yaitu: Dusun Tetebatu (12 RT), Orong Gerisak (8 RT), Lingkung Daye (5 RT), Lingkung Lauk (9 RT) dan Kembang Seri (6 RT). Luas wilayah Desa Tetebatu sekitar 8.098,8 Ha (KONSORSIUM ADBMI AND FRIENDS, 2019).

Lebih lanjut dinyatakan, kondisi perekonomian Desa Tetebatu dengan bentang alamnya yang kaya berpotensi sebagai destinasi wisata alam yang telah cukup lama menjadi tujuan turis mancanegara. Berbanding terbalik dengan mata pencaharian warga. Mata pencaharian yang banyak mereka lirik adalah sebagai TKI ke luar negeri, sementara keluarga yang ditinggalkan berprofesi sebagai petani, buruh tani, peternak, buruh ternak, pedagang dan pemandu wisata. Akan tetapi yang disebutkan dua terakhir, jumlahnya haanya bisa dihitung dengan jari. Hal yang membuat kondisi demikian adalah faktor kepemilikan lahan yang sangat minim dari warga sekitar, ketrampilan dan tata pengelolaan yang belum mumpuni. Untuk potensi ternak di Desa Tetebatu, sebagian besar keluarga beternak sapi. Ternak sapi ini dianggap sebagai investasi atau sejenis tabungan keluarga. Ternak sapi ini bisa dikembangkan secara maksimal oleh masyarakat karena dari sisi keamanan sangat memungkinkan. Didukung dengan ketersediaan pakan ternak sendiri sangat mudah didapat. Pakan ternak yang dikembangkan jenis rumput gajah. Rumput gajah ditanam dengan memanfaatkan lahan di sekitar pinggir sungai, pematang sawah, pinggir jalan dan kebun, sedangkan untuk ternak kecil dikembangkan jenis ayam kampung dan bebek, seperti disajikan pada Tabel 1.

Tabel 1. Jenis dan Populasi Ternak

\begin{tabular}{ccc}
\hline Jenis Ternak & $\begin{array}{c}\text { Jumlah } \\
\text { Pemilik }\end{array}$ & $\begin{array}{c}\text { Jumlah } \\
\text { Populasi }\end{array}$ \\
\hline Sapi & 300 orang & 606 ekor \\
Ayam Kampung & 250 orang & 1.500 ekor \\
Bebek & 20 orang & 250 ekor \\
Ayam Potong & 15 orang & 20.000 ekor \\
\hline Sumber: KONSORSIUM ADBMI AND FRIENDS, \\
2019
\end{tabular}

Tantangan pengembangan usaha yang perlu dilakukan di Desa Tetebatu adalah mengembangkan usaha beternak secara mandiri dengan meningkatkan managemen pemeliharan dan memanfaatkan bahan pakan lokal dan alternatif, karena melihat potensi pertanian dan perkebunan yang besar, sehingga ketersediaan bahan pakan melimpah. Untuk pengembangan peternakan unggas, perlu perbaikan dalam managemen pemeliharaan. Setidaknya ada 3 macam sistem yang digunakan dalam beternak ayam, yaitu sistem ektensif (tradisional), semi intensif dan intensif. Ketiga sistem ini masing-masing mengindikasikan skala kegiatan peternakan itu sendiri, yaitu skala kecil, menengah dan skala besar. Namun sistem intensif tidak cocok untuk ternak ayam kampung dan hanya cocok untuk ternak ayam petelur dan beberapa jenis ayam lainnya. Ayam kampung adalah ayam asli lokal yang sudah terbiasa hidup bebas dan tidak bisa dipelihara dalam kandang yang membuat ruang geraknya terbatas. 
Selain sistem pemeliharaan, hal yang perlu mendapat perhatian adalah masalah penyediaan bahan baku pakan ternak, karena dapat berpengaruh terhadap perkembangan pakan ternak dan perkembangan usaha peternakan. Suatu kenyataan yang terjadi situasi nilai tukar rupiah yang melemah terhadap dollar, maka harga pakan ternak meningkat karena sebagian besar bahan baku pakan masih diimpor. Harga produk peternakan juga menjadi meningkat, akhirnya merugikan usaha peternakan karena daya beli masyarakat juga rendah.

Untuk itu perlu diupayakan mencari sumber bahan pakan alternatif yang dapat mengganti sebagian atau seluruhnya dari suatu jenis bahan pakan. Perlu dipertimbangkan kemungkinan penggunaan bahan pakan inkonvensional yang sifatnya tidak kompetitif dengan kebutuhan manusia, sehingga ditemukan sumber-sumber bahan pakan baru yang kemungkinan mempunyai kualitas yang cukup baik. Hanya saja perlu diperhatikan bahwa bahan pakan jenis inkonvensional ini hendaklah mudah diperoleh dan potensinya (ketersediaannya) cukup banyak, harganya lebih murah serta nilai nutrisinya cukup tinggi dan disukai oleh ternak.

Beberapa penelitian tentang penggunaan bahan pakal lokal dan alternatif telah banyak dilakukan dan perlu disebarkan ke masyarakat melalui kegiatan pengabdian. Hasil penelitian Purnamasari, D.K., dkk. (2015) menggunakan tepung limbah rajungan mampu meningkatkan kualitas eksternal dan warna kuning telur itik secara signifikan. Hasil penelitian Mann (1997) menggunakan Azzola pinnata $20 \%$ mampu meningkatkan pertambahan bobot badan secara signifikan. Selain gulma Azzola pinnata, daun kiyambang juga digunakan sebagai pakan, hasil penelitian Meliandasari, D., dkk. (2015) pemberian kiyambang mampu menghasilkan kualitas daging yang rendah kolesterol dan memberikan imbangan rasio omega- 3 dan omega- 6 yang mendekati rekomendasi.

Pemberian pakan pada unggas dengan menggunakan bahan pakan yang terlebih dahulu di fermentasi telah banyak diteliti dan dilakukan. Praditya (2015) telah menciptakan pakan ayam kampung dengan menggunakan tepung tempe yang merupakan hasil fermentasi kedele kaya akan kandungan asam amino, dan ternyata mampu menghasilkan ayam dengan daging yang lebih sehat karena rendah lemak dengan kandungan protein yang lebih tinggi tanpa residu antibiotik. Lebih lanjut dinyatakan bahwa proses fermentasi dalam tempe dapat menghasilkan enzim-enzim pencernaan seperti amylase, protease, dan lipase yang mengubah senyawa komplek menjadi senyawa yang sederhana. Oladunjoye et al., (2010) meneliti pengaruh substitusi bungkil jagung dengan tepung kulit singkong kering matahari dan yang direndam dengan air abu kayu pada ayam petelur, menghasilkan tidak ada perbedaan yang nyata pertumbuhan bobot badan dan konsumsi pakan pada substitusi $50-80 \%$, namun pada substitusi $50 \%$ produksi telur dan konversi pakan yang paling optimum. Pada profil kualitas telur hamper tidak terdapat perbedaan, kecuali warna kuning telur serta kadar kolesterol lebih rendah pada perlakuan substitusi. Fermentasi kulit singkong mampu menurunkan kadar sianogenik kulit singkong dan menghasilkan enzim lignoselulosa yang mampu menurunkan kadar lignin sampai 52,6\% (Tijani et al., 2012).

Penggunaan bahan pakan lokal limbah pertanian memiliki kendala yaitu rendahnya kandungan protein dan tingginya kadar serat kasar, sehingga selama ini peternak menggunakan masih dalam jumlah yang sedikit karena keterbatasan unggas dalam mencerna bahan pakan berserat. Untuk itu perlu diberikan tambahan informasi dan sosialisasi tehnologi 
pada masyarakat melalui pengolahan bahan pakan berserat melalui proses fermentasi dengan menggunakan berbagai fermentor dalam rangka meningkatkan kandungan protein dan menurunkan kandungan serat kasar bahan pakan, sehingga bahan pakan limbah industri pertanian dapat dimanfaatkan secara maksimal.

Selain pengembangan peternakan ruminasnia dan unggas, Desa Tetebatu berpotensi untuk dikembangkan peternakan lebah Trigona sp. Vegetasi tanaman yang bervariasi seperti tanaman buah-buahan, tanaman berbunga, tanaman sayuran dan tanaman penghasil kayu yang tumbuh subur di Desa Tetebatu merupakan sumber nektar dan polen bagi lebah khususnya lebah trigona. Lebah Trigona sp. adalah salah satu jenis lebah yang mudah untuk dibudidayakan karena sifatnya yang tidak menyengat dan ukuran tubuh yang sangat kecil, serta mudah untuk dikembangkan. Berdasarkan hal tersebut, melalui kegiatan pengabdian ini disampaikan program pembuatan 'Lumbung Trigona Tetebatu' atau Liteba, sebagai lumbung percontohan yang selanjutnya akan dikembangkan oleh masyarakat desa.

Tujuan yang diharapkan setelah kegiatan PPM adalah:

1. Bertambahnya pengetahuan dan wawasan masyarakat tani ternak dan masyarakat lainnya.

2. Meningkatnya semangat masyarakat tani ternak dan masyarakat lainnya dalam mengembangkan usaha peternakan secara mandiri berbasis bahan pakan lokal dan alternatif.

3. Berdirinya 'Lumbung Trigona Tetebatu' sebagai lumbung percontohan.

\section{METODE PELAKSANAAN}

Kegiatan pengabdian masyarakat ini dilaksanakan dalam bentuk antara lain:
1. Diskusi bersama-sama masyarakat tani ternak, pengurus desa, tokoh-tokoh masyarakat dan masyarakat lainnya untuk memecahkan permasalahan yang timbul dan memecahkan permasalahan tersebut dengan solusi yang tepat secara bersamasama serta menggali potensi-potensi yang ada untuk dikembangkan

2. Memberikan pengetahuan dan gambaran untuk mengembangkan usaha beternak unggas dengan metode penyuluhan dan diskusi interactive'.

3. Merumuskan jenis-jenis pakan lokal dan alternatif yang dapat digunakan sebagai pakan baik ternak besar maupun kecil.

4. Menyampaikan program mahasiswa yaitu Lumbung Trigona Tetebatu (LITEBA) dan dilanjutkan pembuatan Liteba sebagai percontohan.

5. Melakukan evaluasi dan apabila dari kegiatan evaluasi masyarakat yang ikut banyak dan antusias serta semangat dalam mengikuti program pengabdian, maka akan dilakukan pendampingan selanjutnya.

6. Merumuskan bersama program lanjutan yang harus segera dilaksanakan dan dibutuhkan masyarakat desa untuk dimasukkan dalam program kerja desa, sehingga masyarakat lebih terarah dan usaha peternakan memberikan hasil yang maksimal

\section{HASIL DAN PEMBAHASAN}

Kegiatan pengabdian dilaksanakan berdasarkan hasil survei, bahwa Desa Tetebatu memiliki potensi yang besar dalam hal penyediaan sumber-sumber bahan pakan yang berupa limbah-limbah pertanian dan perkebunan yang selama ini belum dimanfaatkan sebagai pakan ternak, baik ternak ruminansia maupun non ruminansia. Desa Tetebatu berada dalam Kecamatan Sikur, memiliki luas wilayah yang merupakan lahan 
sawah 2771 ha, lahan perkebunan 374 ha, dan lahan hutan negara 3881 ha (BPS Kabupaten Lombok Timur, 2020). Berbagai limbah pertanian, perkebunan, dan kehutanan belum terolah dan termanfaatkan dengan baik.

Kegiatan pengabdian dihadiri sebanyak 35 peserta, yang terdiri dari Kepala Desa dan tokoh pemuda desa, pejabat Dinas Peternakan Kabupaten Lombok Timur, tim pendamping bidang peternakan wilayah Kecamatan Sikur, alumni dan mahasiswa Fakultas Peternakan, serta masyarakat tani ternak Desa Tetebatu. Kegiatan diawali dengan pemberian sambutan dari Kepala Desa Tetebatu, dilanjutkan sambutan dari Pejabat Dinas Peternakan Kabupaten Lombok Timur, selanjutnya pemberian materi penyuluhan dari tim pengabdian Fakultas Peternakan Unram, dan terakhir adalah penyampaian program dari mahasiswa yaitu menjadikan Desa Tetebatu sebagai 'Lumbung Trigona Tetebatu'.

Materi pengabdian yang disampaikan yaitu managemen beternak unggas dengan sistim pemeliharaan yang efisien dan penggunaan bahan pakan lokal yang ada di sekitar Kabupaten Lombok Timur. Permasalahan yang ada dalam beternak unggas adalah terletak pada masalah pakan, karena $70 \%$ dari biaya produksi adalah untuk biaya pakan. Umumnya pakan-pakan ternak unggas terdiri dari: pakan butiran (jagung, beras, kacang kacangan, milet, jewawut, ketan hitam, gabah dII), pakan komplit atau pakan jadi, dan pakan asal hewani (bekicot, tepung ikan, siput, ikan rucah, ikan sapu sapu, limbah rajungan, cangkang udang dII) serta pakan konsentrat. Pakan komplit adalah pakan yang diproses dengan teknologi modern yang higinies yang memiliki nilai gizi dengan kisaran protein 17$23 \%$ dan telah disusun sesuai kebutuhan ternak serta pemberiannya tidak perlu dicampur dengan bahan pakan lain. Pakan konsentrat terdiri dari 2 jenis yaitu pakan konsentrat sumber energi dan pakan konsentrat sumber protein yang memiliki kandungan protein mencapai $27-42 \%$ dan biasanya pemberiannya masih dicampur dengan bahan pakan lainnya (Universal Agri Bisnisindo, 2002).

Untuk mengatasi tingginya biaya pakan, maka solusinya adalah dengan memanfaatkan bahan-bahan pakan lokal yang ada. Bahan-bahan pakan berupa limbah-limbah pertanian, perkebunan, dan perikanan masih memiliki kandungan gizi dan dapat ditingkatkan dengan proses pengolahan terlebih dahulu. Hasil penelitian Purnamasari, dkk. (2015) yang meneliti kualitas telur itik yang diberi pakan limbah rajungan, menunjukkan bahwa pemberian limbah rajungan memberikan pengaruh yang lebih baik $(P<0,01)$ terhadap kerabang telur dan warna kuning telur $(P<0,05)$, sedangkan indeks kuning telur mengalami penurunan yang sangat nyata $(P<0,01)$ dengan penambahan limbah rajungan $4 \%$ dan $8 \%$, sehingga penggunaan limbah rajungan dalam pakan itik bermanfaat dalam menghasilkan telur dengan kualitas yang lebih baik.

Irianto, A.F., dkk. (2019) yang meneliti tentang potensi ikan sepat yang ada di Lebo taliwang Kabupaten sumbawa Barat sebagai pakan unggas, dihasilkan bahwa ikan sepat memiliki kadar bahan kering berkisar 96.4296.29\%. Kadar berat kering ikan sepat adalah $27 \%$, sehingga jika $37 \mathrm{~kg}$ ikan sepat segar setelah dikeringkan hingga konstan dapat menjadi sekitar $10 \mathrm{~kg}$ Bila dibandingkan dengan tepung ikan kadar airnya lebih tinggi yaitu 9.20\% (Haryati, dkk., 2010 dan Kartadistra, 1994) dan hasil penelitian Purnamasari, dkk (2011) ikan sapu-sapu segar memiliki kadar bahan kering berkisar 26.42-29.33\%. Lebih lanjut dihasilkan bahwa tepung ikan sepat mengandung kadar abu (25.23\%), angka ini lebih tinggi bila dibanding tepung ikan (12.81\%) dan lebih rendah bila dibandingkan tepung ikan sapu-sapu (36.31\%). Tingginya kadar abu pada 
tepung ikan sepat dan ikan sapu sapu disebabkan karena struktur pertulangan yang mendominasi tubuh ikan. Tingginya kadar abu mengindikasikan kadar mineral pada ikan sepat dan sapu sapu berpotensi untuk dijadikan sebagai pakan unggas khususnya unggas petelur yang berperan dalam pembentukan kerabang telur dan menjaga produksi telur tetap stabil.

Kandungan serat kasar tepung ikan sepat $(0.97 \%)$ sedikit lebih rendah atau hampir sama dengan tepung ikan (1\%), sedangkan serat kasar ikan sapu-sapu sangat tinggi (3.18\%) yang terkandung pada bagian kulit dan kepala yang teksturnya lebih keras bila dibandingkan ikan sepat. Namun kadar serat kasar pada ke-3 tepung ikan ini di bawah standar maksimal yang ditentukan oleh SNI 01-2715-1996, yaitu mutu I maks $1.5 \%$, mutu II maks $2.5 \%$, dan mutu III maks 3\% (GMPT, 2019). Kadar protein kasar tepung ikan sepat (53.13\%) jauh lebih tinggi dibandingkan tepung ikan sapu-sapu (36.15\%) dan sedikit di bawah tepung ikan yang biasa digunakan peternak (62\%). Kadar protein kasar tepung ikan sepat dan ikan sapu sapu masuk kategori mutu III SNI 01-2715-1996 yaitu minimal $45 \%$, tepung ikan masuk dalam kategori mutu II yaitu min 55\%, sedangkan mutu I minimal 65\% (GMPT, 2019).

Bahan pakan sumber hewani selain unggul karena kandungan proteinnya juga unggul dengan kandungan mineral $\mathrm{Ca}$ dan $\mathrm{P}$. Kadar Ca dan P ikan sepat (2.88 dan 0.37\%) di bawah dari pada ikan sapu-sapu (3.99 dan 0.92\%) dan tepung ikan (4.00 dan 1.03\%). Kandungan mineral $\mathrm{Ca}$ dan $\mathrm{P}$ ini diharapkan berperan dalam menghasilkan produksi telur yang tinggi dengan kualitas telur yang lebih bagus. Selain limbah perikanan yang merupakan bahan pakan sumber hewani, limbah-limbah pertanian dan perkebunan juga mengandung nutrisi yang cukup sebagai bahan pakan. Hasil penelitian Basri, M.H. (2018) menunjukkan bahwa fermentasi daun eceng gondok menggunakan EM-4 mampu meningkatkan kualitas nutrisi daun eceng gondok dengan dosis fermentasi terbaik terdapat pada dosis $15 \%$ yang dapat meningkatkan kadar protein kasar sebesar 4,34\%, menurunkan serat kasar sebesar 2,07\% dan meningkatkan kadar lemak kasar sebesar $1,57 \%$. Daun eceng gondok fermentasi memiliki potensi untuk dijadikan bahan pakan alternatif ternak unggas.

Materi pengabdian juga disampaikan tentang pengolahan bahan pakan limbah pertanian dan perikanan melalui proses fermentasi untuk meningkatkan kualitas protein dan menurunkan kadar serat kasar yang tinggi pada limbah hasil pertanian dan perkebunan. Suasana penyuluhan disajikan pada Gambar 1.

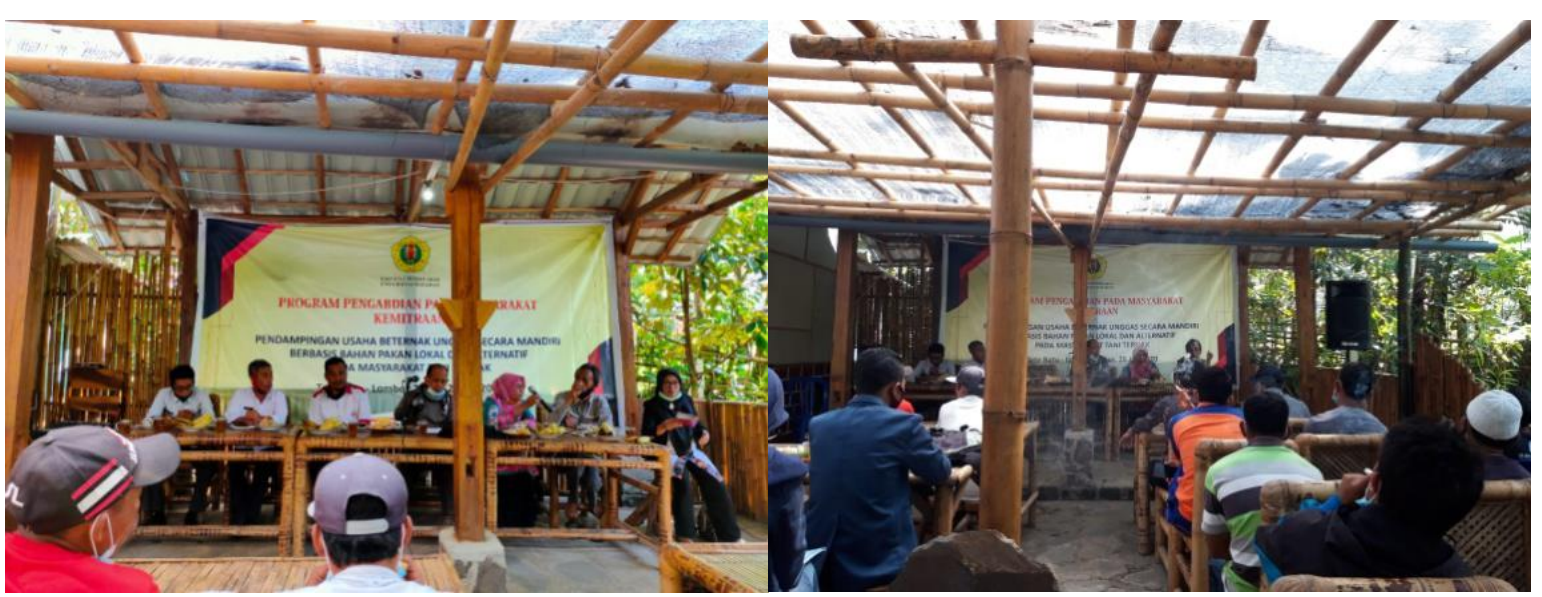

Gambar 1. Suasana penyampaian materi 
Pada sesi diskusi, muncul berbagai permasalah-permasalahan yang diungkap peserta pengabdian dan sebagian besar masyarakat tani ternak memiliki motivasi dan semangat mengembangkan usaha peternakan baik ternak unggas maupun ternak sapi, namun terkendala masalah pakan dan rendahnya pengetahuan masyarakat dalam memanfaatkan dan mengolah pakan-pakan lokal. Selain itu masalah permodalan menjadi kendala dalam menjalankan usaha terutama usaha ternak unggas, sehingga perlu peran serta dari instansi-instansi yang terkait untuk membantu masyarakat tani ternak. Pihak pejabat Dinas Peternakan Kabupaten Lombok Timur yang hadir berkomitmen untuk mendampingi masyarakat tani ternak dalam mengembangkan usahanya.

Kegiatan selanjutnya yaitu penyampaian program dari mahasiswa yaitu 'Lumbung Trigona Tetebatu' (LITEBA). Program LITEBA adalah program yang menjadikan Desa Tetebatu sebagai lumbung peternakan lebah Trigona sp. dengan memberdayakan pemuda- pemuda desa untuk memelihara lebah trigona. Program ini didasarkan potensi ketersediaan tanaman penghasil nektar dan polen yang melimpah, baik tanaman buah-buahan, tanaman hutan, maupun tanaman berbunga yang merupakan sumber pakan lebah trigona. Berdasarkan potensi tersebut, masyarakat hanya membuat lumbung dan kotak-kotak pemeliharaan lebah yang tidak membutuhkan banyak biaya dan waktu, selanjutnya lebah akan hidup, mencari makan sendiri, dan menghasilkan madu terus menerus. Produk madu yang dihasilkan dapat menjadi produk unggulan Desa Tetebatu untuk dipasarkan pada masyarakat lokal dan luar kabupaten Lombok Timur, bahkan para wisatawan yang banyak berkunjung ke Desa Tetebatu.

Berdasarkan hasil evaluasi program yang dilakukan dua bulan setelah kegiatan pengabdian, telah berdiri lumbung trigona dan telah diproduksi madu trigona serta telah dipasarkan ke banyak pihak, seperti tersaji pada Gambar 2.

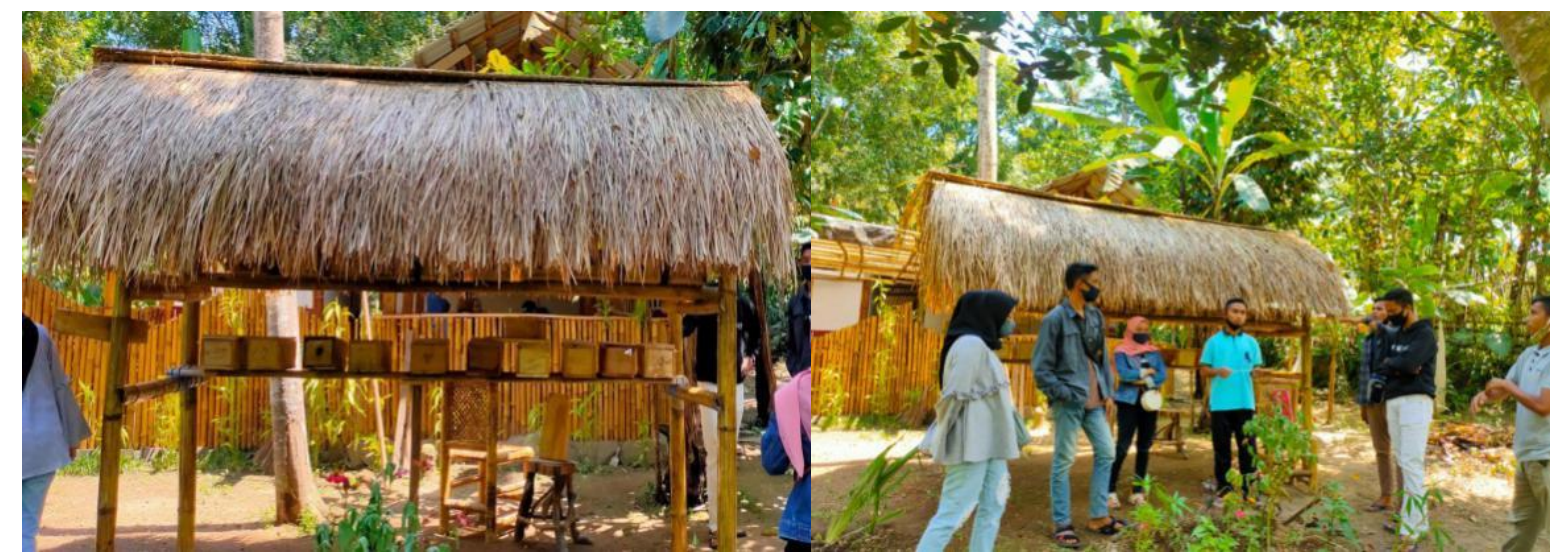

Gambar 2. Lumbung trigona dan kunjungan dari pembeli

Mahasiswa mengajarkan cara budidaya lebah trigona, diawali dengan pembuatan lumbung, kotak koloni, dan pemecahan koloni, pemeliharaan, penanganan panen, pengemasan produk madu, dan cara $\begin{array}{lrr}\text { pemasaran. } & \text { Selain itu mahasiswa } \\ \text { menyampaikan } & \text { pentingnya menjaga }\end{array}$ lingkungan atau habitat lebah dan ketersediaan tanaman penghasil nektar dan polen sebagai sumber pakan lebah dengan melakukan 
perbanyakan tanaman, terutama tanaman berbunga. Pemasaran dilakukan melalui 2 cara yaitu langsung dan tidak langsung. Secara langsung dengan mendatangi konsumenkonsumen atau konsumen yang datang ke lokasi peternakan, secara tidak langsung melalui media sosial berupa whatsapp, facebook, instagram, twitter, dan lain-lain. Penyampaian tehnik budidaya lebah dan produk madu yang dihasilkan disajikan pada Gambar 3.

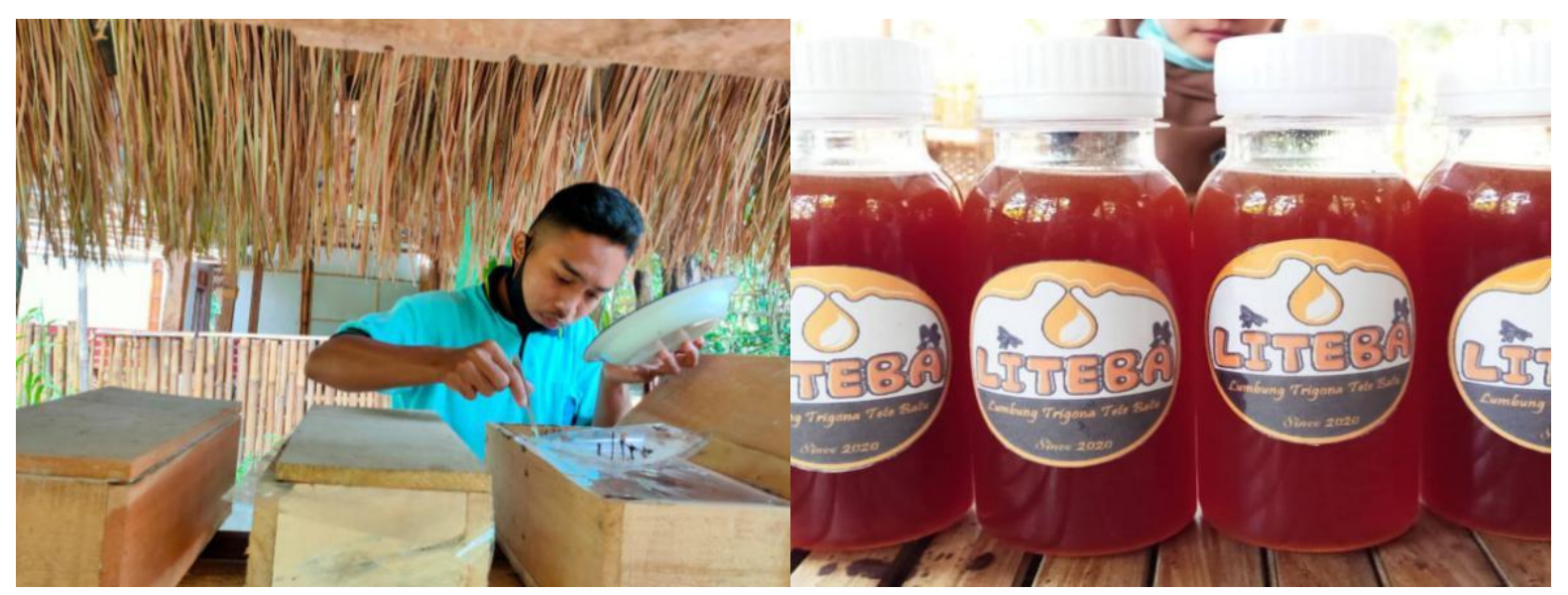

Gambar 3. Produksi Madu Trigona Tetebatu

Lebah Trigona sp. adalah lebah yang mudah untuk dibudidayakan oleh masyarakat, karena lebah ini adalah lebah yang tidak menyengat. LITEBA akan menjadi usaha percontohan yang selanjutnya diharapkan masyarakat Desa Tetebatu dapat mengembangkan usaha budidaya lebah di halaman rumah masing-masing. Produk madu yang dihasilkan dapat dikonsumsi sendiri bersama keluarga untuk meningkatkan kesehatan dan bila produksi telah melimpah dapat dijual sehingga dapat meningkatkan penghasilan masyarakat Desa Tetebatu.

\section{KESIMPULAN DAN SARAN}

Kesimpulan

Kegiatan pengabdian berhasil dilakukan dan sesuai target yang diharapkan yaitu adanya peningkatan pengetahuan dan motivasi dalam melakukan usaha budidaya ternak serta terbangunnya Lumbung Trigona Tetebatu yang telah menghasilkan dan dapat menjadi percontohan desa lain.
Saran

Agar kegiatan pengabdian dapat maksimal dilaksanakan dan menghasilkan produk yang bermanfaat untuk dikembangkan maka perlu pembinaan yang berkelanjutan dari berbagai pihak.

\section{UCAPAN TERIMA KASIH}

Ucapan terima kasih disampaikan ke Fakultas Peternakan Universitas Mataram bersama Lembaga Penelitian dan Pengabdian Kepada Masyarakat Universitas Mataram yang telah mendanai kegiatan pengabdian melalui dana PNBP tahun 2020, pengurus dan tokoh masyarakat desa Tetebatu atas kerjasamanya, serta alumni dan adik-adik mahasiswa atas peran sertanya dalam membina masyarakat desa menjadi lebih baik.

\section{DAFTAR PUSTAKA}

Badan Pusat Statistik Kabupaten Lombok Timur, 2020. Lombok Timur Dalam Angka. BPS Kabupaten Lombok Timur. 
Basri, M.H., 2018. Kajian Nutrisi Daun Eceng Gondok (Eichornia crassipes) yang difermentasi dengan em-4 dan potensinya sebagai pakan unggas. Skripsi. Fakultas Peternakan Universitas Mataram.

GMPT, 2019. SNI Untuk Bahan Pakan.

https://asosiasi-

gpmt.blogspot.com/p/bahan-

pakan.html (19 Desember 2019).

Haryati. Zainuddin dan Dwi, S. P. 2010.

Pengaruh Tingkat Substitusi Tepung Ikan

Dengan Tepung Monggot dan Tubuh Ikan Bandeng.Makassar.

Irianto, A.F., Taufikkurrahman, D.K. Purnamasari, Erwan, KG.Wiryawan, Syamsuhaidi, Pardi, 2019. Kajian Potensi Ikan Sepat Rawa (Trichopus trichopterus) Lebo Taliwang Kabupaten Sumbawa Barat Sebagai Pakan Unggas. Jurnal IImu dan Teknologi Peternakan Indonesia. Volume 5 (1) 35 - 45; Juni 2019

Kartadistra. H. R. 1994. Pengelolaan Pakan Ayam Kiat Meningkatkan Keuntungan dalam AgribisnisUnggas.Yogyakarta.

Konsorsium ADMI and Friends, 2019. Analisis Ekonomi Dan Sejarah buruh Migran Desa Tetebatu Kecamatan sikur Kabupaten Lombok Timur.

Mann, 1997. Penggunaan Tepung Eceng Gondok (Eichornia crassipes Mart) dan Azzola pinnata Dalam ransum ternak Itik Periode Pertumbuhan. J. Peternakan Lingk., 3(2):13-20.
Meliandasari, D., B. Dwiloka, dan Edjeng Suprijatna, 2015. Optimalisasi Daun Kiyambang (Salvinia molesta) Untuk Penurunan Kolesterol Daging dan Peningkatan kualitas Asam Lemak Esensial.

Olamdujoye IO, Ojebiyi O, Aman OA, 2010. Offect of feeding processed cassava peel meal based diet on the performance characteristic egg quality and blood profile of laying chicken. Agri Trop Subtrop. 43:119-126.

Praditya, I.M., 2015. Ciptakan Ransum Pakan ayam Kampung. https://www.ugm.ac.id Purnamasari, D.K., Asnawi, Abdul Aziz 2011. Evaluasi nilai nutrisi dan logam berat ikan sapu sapu (Kajian potensi ikan sapu sapu sebagai pakan itik petelur). Jurnal Penelitian Universitas Mataram Vol. 2 No. 16, Februari 2011.

Purnamasari, D.K., K.G. wiryawan, Erwan, dan L.A. Paozan, 2015. Potensi Limbah Rajungan (Portunis pelagicus) Sebagai Pakan Itik Petelur. Jurnal Peternakan Sriwijaya, vol. 4 no. 1, Juni 2015, pp. 1119.

Tijani IDR, Jamal P., Alam MZ, Mirghani MES, 2012. Optimization of cassava peel medium to on enriched animal feed by the white rot fungi. Int Food Res. 19:427432.

Universal Agri Bisnisindo. 2002. Global Feed. Trobos No. 32 Mei 2002. 